\title{
Erratum: 'n Viering van Afrikaans en Jaap Steyn
}

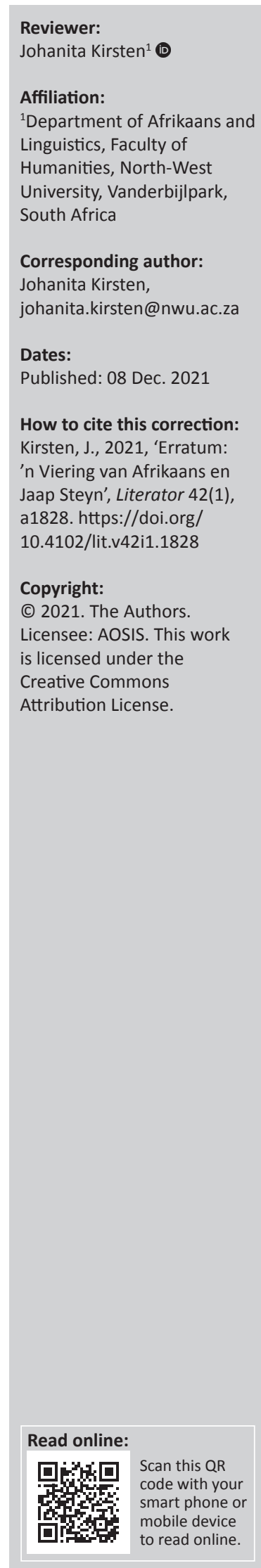

In the version of this article initially published, Kirsten, J., 2020, "n Viering van Afrikaans en Jaap Steyn', Literator 41(1), a1735. https:/ / doi.org/10.4102/lit.v41i1.1735, the article section was given incorrectly. The correct section should be Book Review instead of Original Research.

This correction does not alter the study's findings of significance or overall interpretation of the study's results. The publisher apologises for any inconvenience caused. 


\section{'n Viering van Afrikaans en Jaap Steyn}

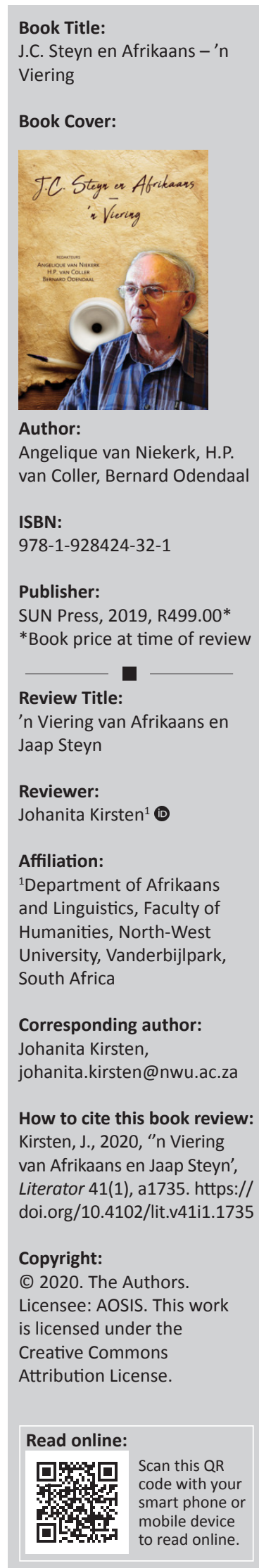

'n Wye gehoor van lesers sal nut en genot uit hierdie boek put. Vir die taalkundige is daar hoofstukke wat op taalkundige temas fokus. Vir die letterkundige is daar literêre hoofstukke, asook gedigte en 'n kortverhaal. Ook die gewone leser sal heelwat van die boek sinvol vind, aangesien die navorsingshoofstukke meestal redelik toeganklik is, en oor onderwerpe handel wat enigeen met ' $n$ belangstelling in Steyn se werk, interessant sal vind.

Die verskeidenheid temas en tekstipes in hierdie versamelwerk illustreer iets van die veelfasettige werk van die persoon aan wie dit opgedra is - J.C. (Jaap) Steyn. Die boek word ingelei met die briefwisseling tussen Steyn en Elize Botha. Verder is daar twee tipes tekste ingesluit: literêre bydraes, en navorsingsbydraes. Die literêre bydraes bestaan uit nege gedigte en 'n kortverhaal deur verskillende outeurs. Die navorsingshoofstukke is 'n kombinasie van literêre beskouings en taalkundige ondersoeke. Elkeen van hierdie bydraes handel óf eksplisiet oor Steyn en 'n aspek van sy werk, óf het duidelike raakpunte met sy lewe en werk.

Die versameling tekste in die boek kan maklik soos'n losse versameling lyk, maar dit is misleidend - die temas van Afrikaans en die Afrikaner, en van woordspeling en -vernuf bind alles saam.

Die meeste van die gedigte speel op die een of ander manier terug op Steyn se bekende gedig 'Woord en sin'. Dit kan gesien word met die gebruik van woord(e)(-) ('spitsberaad'; 'Onomastiek'; 'Apokopoësie'; 'die evolusie van skryf') en/of $\sin (n e)(-)$ ('spitsberaad'; 'Ernest Hemingway'; 'Die neukery met nie', 'Apophrades'), en 'Boekensteynfontein' sinspeel op die titel van Steyn se digbundel met 'die grammatika van tuistebou' (r. 46). Die tipe woordspel en woordvernuf waarvoor Steyn bekend is (Gouws 1983:11; Hugo 2016:713) figureer ook in die gedigte. Daar is verder eksplisiete verwysings na Afrikaans of die taal ('Boekensteynfontein'; 'spitsberaad'; 'Onomastiek'; 'Apophrades'), kentekenend van Steyn se liefde vir Afrikaans en sy taalaktivisme. Sommige gedigte wys ook iets van Steyn se lewe en grootwordwêreld (Hugo 2016:712) soos 'spitsberaad' se verwysing na 'vrystaatson' (r. 15) en 'JCS' wat praat van 'Vrystaatse skalie' (r. 8) en 'Petrus Steyn' (r. 11). Ook die kortverhaal skakel direk met Steyn en sy werk, deur 'n aanhaling uit Die grammatika van liefhê en die fokus op 'n woord.

Die hoofstukke met 'n literêre fokus, bied insigte oor Steyn se prosatekste en biografieë, of sluit aan by welbekende temas uit sy werk soos grense (Scheepers 2016:714) in Viljoen se hoofstuk 9. Die briefwisseling wat in die voorspel weergegee word, illustreer verder iets van Steyn se skryfproses en die vraagstukke en vertwyfelings waarmee hy in nederigheid geworstel het. Wat duidelik blyk uit die briefwisseling en die literêre hoofstukke, is hoe Steyn nog altyd doelbewus met woorde (en sinne) omgaan, en hoeveel aandag hy aan die moontlike nuanses skenk wat met woordspel en -vernuf uitgedruk kan word.

In die taalkundige bydraes kom onderskeie temas aan bod wat aansluit by Steyn se werk deur die jare - die taalgeskiedenis en geskiedskrywing van Afrikaans; die Genootskap van Regte Afrikaners (GRA), die taalbewegings en die standaardisering van Afrikaans; die vestiging van Afrikaans as wetenskapstaal én die Afrikaanse taalwetenskap; taalbeleid in Suid-Afrika; Afrikanerskap, Afrikaans en identiteit. Hierdie bydraes bied 'n historiese, asook hedendaags taal-sosiologiese beeld van Afrikaans en die Afrikaanse taalwetenskap - die diep spore wat Steyn in die taalwetenskap getrap het, blyk duidelik.

Daar is slegs enkele meer kritiese opmerkings. Hier en daar het 'n tikfout ingeglip, veral blykbaar by hakies (sien p. 192 en p. 232), hoewel dit glad nie opvallend baie is nie. Verder sou 'n paar van die hoofstukke kon baat by 'n meer eksplisiete skakeling met Steyn en sy werk, veral vir lesers wat nie noodwendig met die verskeidenheid van sy publikasies bekend is en die temas wat daarin vervat is nie - soos hoofstuk 5 waar 'n leser bekend moet wees met Steyn se taalaktivisme om die relevansie te begryp, en hoofstuk 9 waar die leser moet weet van Steyn se werk met die tema van grense. 
Hierdie versamelwerk is 'n gepaste viering van J.C. Steyn se lewe en werk, met bydraes so uiteenlopend (en tog tematies verwant) soos Steyn se eie publikasies. Dit sal nuttige leesstof aan letterkundiges, sowel as taalkundiges verskaf, asook enige gewone leser wat belangstel in Afrikaans as taal in die breër Suid-Afrikaanse konteks.

\section{Literatuurverwysings}

Gouws, R.H., 1983, 'Taalkundige interessanthede in J.C. Steyn se gedig "woord en $\sin ^{\prime \prime \prime}$, Klasgids 18(2), 11-17.

Hugo, D. 2016, 'J.C. Steyn (1938-): Poësie', in H.P. van Coller (red.), Perspektief \& Profiel: 'n Afrikaanse literatuurgeskiedenis, 2 de uitg., bl. 712-715, Van Schaik, Pretoria.

Scheepers, R., 2016, 'J.C. Steyn (1938-): Prosa', in H.P. van Coller (red.), Perspektief \& Profiel: 'n Afrikaanse literatuurgeskiedenis, 2de uitg., bl. 715-720, Van Schaik, Pretoria. 